\title{
Countering COVID-19 in 2021 and Beyond: More Cooperation is Required Between the Governments of China and the USA
}

\author{
Richard Danzig ${ }^{*}$
}

The achievements of the global scientific community in battling coronavirus disease 2019 (COVID-19) have been unprecedented, impressive, and inadequate.

Unprecedented and impressive because this previously unknown virus was sequenced within one month of its appearance (1) and because safe and efficacious vaccines to counter it were developed within the year. Impressive also because, though they were imperfect, drugs and therapeutic interventions were developed to reduce morbidity and mortality and nonpharmaceutical interventions (lockdowns, distancing, masks (2), and other measures) were implemented to retard the spread of the virus.

The People's Republic of China and the United States of America were leaders in all these efforts. China has particular cause for pride in its remarkably effective control of an exceptionally challenging pandemic (3) and in its efforts to help other countries by exporting its vaccines and medical supplies.

Clearly though, even herculean efforts have not protected the global community. By even conservative reckonings more than two million people have died from COVID-19. The global pandemic continues. Present mutations (4-5) are likely to expand contagion and present risks to the effectiveness of our medical and non-pharmaceutical countermeasures. Economic damage, already immense, is expanding and likely to be long-lasting for many.

The area where we have most underperformed is political. The United States and China - the two countries with the most resources and deepest pools of technical talent - have the greatest responsibilities in this respect. This is true not just about what has occurred, but also about what will occur as this pandemic continues and as it is succeeded by other pandemics.

Probably everyone who reads this short article understands that COVID-19 is a challenge to humankind, not just to one nation or continent. And what is undeniable about this dynamic pandemic will be true of the next one and the one after that until we treat epidemics and pandemic threats as global problems that require global solutions (G). Stepping up to that requires not just the collaborations of individual scientists and organizations but as governments.

The United States and the Soviet Union achieved cooperation in this regard. Even in the worst days of the Cold War, testing and development of the polio and smallpox vaccines were, for example, shared between the two nations (7). China and the United States similarly worked side by side on every pandemic since severe acute respiratory syndrome (SARS). But our governments have failed to cooperate in our responses to COVID-19.

The vaccines in which both nations can take much pride were developed with no bilateral coordination and little sharing of trial data, production techniques, and distribution plans. This contrasts with the technical support provided by Western organizations to help put the first Chinese vaccine - for Japanese encephalitis - on the global market. Both nations would benefit from cooperation on COVID-19 vaccines - for example, by sharing detailed data on serious adverse effects as these vaccines are deployed and by having regulatory agencies in both countries review and validate these and other pharmaceutical products for global use.

The American mRNA vaccines provide a new technology that is unusually precisely targeted and that can be adapted rapidly to new viruses (or variants of COVID-19) as they emerge. The leading Chinese whole virus-inactivated and attenuated viral vaccines have the strengths of being more broadly targeted. China is developing its own mRNA vaccine capabilities and the US is funding some attenuated viral vaccines, but each country could help the other towards these ends. Diversity in our vaccine armamentarium may be particularly rewarding as the virus mutates.

Global distribution is a hodgepodge of arrangements that shortchange the world. Cooperative purchasing through the World Health Organization (WHO) and non-governmental organizations like Global Alliance for Vaccines and Immunisation (GAVI) and the Coalition for Epidemic Preparedness Innovations 
(CEPI) will save lives. It will also benefit China and the United States by reducing and then extinguishing the pandemic, reducing the likelihood of viral mutations spreading from a global reservoir back into our countries. The US and China have not, though, found a way to make these organizations a very fruitful arena of cooperative activity between our countries.

Cooperation is most important with respect to surveillance. Both nations recognize that zoonotic diseases are on the rise and that this pandemic — not this century's first - will not be its last. Sentinel systems and zoonotic investigations - including about the origins of COVID-19 - need to be conducted with shared information and expertise that is transparently, rapidly, and cooperatively employed (8).

We know that wherever it starts, a fire can destroy the whole forest. Accordingly, we fight fires by providing surveillance throughout the forest and we respond by focusing and coordinating all our resources to stamp out small fires before they become catastrophic. We need to treat the threat of pandemics the same way.

And - should one more example be desired - we now have different data derived from different experiences with COVID-19. China has longer experience with victims and wider experience with the rewards of non-pharmaceutical interventions and some treatments. America has many more cases and much more diversity in its non-pharmaceutical measures. Therefore, it has much more data. We need to pool our understanding.

Better cooperation will yield what science was designed for: the growth of knowledge and improvements in human health. Beyond this, it can achieve something that transcends science. It can be an example of how the best educated and most collaborative amongst us can cooperate for the betterment of mankind.

In 2020 politics undermined science. In 2021 let us have science improve our politics.

doi: $10.46234 / \mathrm{ccdcw} 2021.038$

\# Corresponding author: Richard Danzig, rjdanzig@gmail.com.

Submitted: January 28, 2021; Accepted: February 01, 2021

\section{REFERENCES}

1. Tan WJ, Zhao X, Ma XJ, Wang WL, Niu PH, Xu WB, et al. A novel coronavirus genome identified in a cluster of pneumonia cases Wuhan, China 2019-2020. China CDC Wkly 2020;2(4):61-2. http://weekly.chinacdc.cn/en/article/doi/10.46234/ccdcw2020.017

2. Jiang TX, Wang $H$, Gao GF, Jiang XM. Wearing face masks - the simple and effective way to block the infection source of COVID-19. China CDC Wkly 2020;2(16):268 - 9. http://dx.doi.org/10.46234/ ccdcw2020.069.

3. Li H , Gao GF. Highly effective stratified hub-and-spoke nonpharmaceutical intervention provides new insight into the prevention of COVID-19 transmission. China CDC Wkly 2020;2(51):985-6. http://dx.doi.org/10.46234/ccdcw2020.263.

4. Chen HY, Huang XY, Zhao X, Song Y, Hao P, Jiang H, et al. The first case of new variant COVID-19 originating in the United Kingdom detected in a returning student - Shanghai Municipality, China, December 14, 2020. China CDC Wkly 2021;3(1):1 - 3. http://dx.doi.org/ $10.46234 / \mathrm{ccdcw} 2020.270$.

5. Chen FJ, Li BS, Hao P, Song Y, Xu WB, Liu NK, et al. A case of new variant COVID-19 first emerging in South Africa detected in airplane pilot - Guangdong Province, China, January 6, 2021. China CDC Wkly 2021;3(2):28 - 9. http://dx.doi.org/10.46234/ccdcw2021.007.

6 . Rodewald LE. Forty and twenty years ago and now - virus elimination successes and new challenges. China CDC Wkly 2020;2(50):953 - 4. http://dx.doi.org/10.46234/ccdcw2020.259.

7. Hotez PJ. Russian-United States vaccine science diplomacy: preserving the legacy. PLoS Negl Trop Dis 2017;11(5):e0005320. https://www. ncbi.nlm.nih.gov/pmc/articles/PMC5444589/.

8. Wu D, Elliott C. Sino-EU intergovernmental collaboration in the campaign against the COVID-19 pandemic on food via EU-China-Safe framework. China CDC Wkly 2021;3(2):39 - 40. http://dx.doi.org/10. $46234 / \mathrm{ccdcw} 2021.010$.

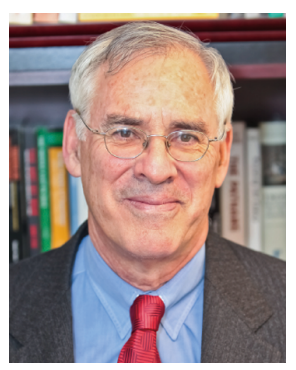

Richard Danzig, PhD

Senior Advisor, Johns Hopkins Applied Physics Laboratory

Chair, Advisory Panel for Idaho National Laboratories' Innovation Center

Director, Center for a New American Security

Director, Saffron Hill Ventures 